\title{
Prevalence of recognition and reporting of child physical abuse by dental surgeons and associated factors
}

\author{
Prevalência de identificação e notificação de abuso físico infantil \\ por dentistas e fatores associados
}

Laís Soares Nunes (https://orcid.org/0000-0003-0584-7756) ${ }^{1}$

Fernando Silva-Oliveira (https://orcid.org/0000-0003-3167-9362) ${ }^{2}$

Flávio Freitas Mattos (https://orcid.org/0000-0002-6052-2762) ${ }^{2}$

Fernanda Bartolomeo Freire Maia (https://orcid.org/0000-0001-8083-9831) ${ }^{1}$

Efigenia Ferreira e Ferreira (https://orcid.org/0000-0002-0665-211X) ${ }^{2}$

Patrícia Maria Pereira de Araújo Zarzar (https://orcid.org/0000-0002-6952-5767) ${ }^{1}$

${ }^{1}$ Departamento de Saúde Bucal da Criança e do Adolescente, Universidade Federal de Minas Gerais. Av. Presidente Antônio Carlos 6627, Pampulha. 31270-90 Belo Horizonte MG Brasil. lais08sn@gmail.com ${ }^{2}$ Departamento de Odontologia Social e Preventiva, Universidade Federal de Minas Gerais Belo Horizonte MG Brasil.
Abstract Studies evaluating the factors associated with under reporting and with the recognition and reporting of child physical abuse are scarce and highly necessary. This study aimed to assess the prevalence of recognition and reporting of child physical abuse (CPA) by Brazilian dentistsin primary care and associated factors. A cross-sectional study was carried out with a representative sample of dentistsfrom the Family Health Strategy in Belo Horizonte. A self-administered questionnaire validated to Brazilian Portuguesewas used for data collection. Statistical analysis included univariate and multiple analyses through Poisson regression. A total of 181 dentists participated in the study. Among them, 73 (40.3\%) had already recognized some cases of CPA, but only $11(6.1 \%)$ ended up reporting. Dentists with six to 19 years of experience as a municipal worker presented 2.38 times $[P R=2.38$ (95\%CI: 1.294.41)] more probability to recognize cases of CPA than the ones with less than six years. Having a graduate degree with a major in childcare $[P R=$ 4.50 (95\%CI: 1.08-18.68)] was associated with a larger number of reports. The employment duration as municipal worker was positively associated with the recognition of CPA cases and the prevalence of reporting was low.

Key words Child abuse, Mandatory reporting, Family Health Strategy, Violence, Dentists
Resumo Estudos que avaliem os fatores associados à subnotificação e às dificuldades dos dentistas para identificar e notificar abuso físico infantil são escassos e necessários. Este estudo teve como objetivo investigar a prevalência de identificação e de notificação de abuso físico infantil (AFI) e fatores associados por dentistas da atenção primária. Trata-se de um estudo transversal com amostra representativa dos dentistas da Estratégia Saúde da Família de Belo Horizonte. Para a coleta de dados foi utilizado um questionário autoaplicável, validado para uso no Brasil. A análise estatística incluiu análise univariada e múltipla pela regressão de Poisson. Um total de 181 profissionais participaram do estudo. Destes, 73 (40,3\%) já identificaram algum caso de AFI, mas apenas 11 (6,1\%) realizaram a notificação. Dentistas com seis a 19 anos de trabalho no município apresentaram probabilidade 2,38 vezes [RP $=2,38$ (CI 95\%: 1,294,41)] maior de identificar casos de AFI do que aqueles com menos de seis anos de atuação. Possuir pós-graduação com foco em crianças $[P R=$ 4,50(CI 95\%: 1,08-18,68)] esteve positivamente associado a um maior número de notificações. $O$ tempo de trabalho no município esteve associado à identificação de casos de AFI. A prevalência de notificação encontrada foi baixa.

Palavras-chave Maus-tratos infantis, Notificação, Estratégia Saúde da Família, Violência, Dentistas 


\section{Introduction}

Since children and adolescents are more vulnerable and dependent, they are often subjected to abuse which, in most cases, occurs in their homes and it is perpetrated by closer individuals ${ }^{1-4} \cdot \mathrm{Ev}^{-}$ ery year, millions of children around the world fall victim to or witness physical, sexual, and emotional abuse ${ }^{4,5}$.

Child maltreatment is often classified into four types: neglect, sexual abuse, physical abuse, andpsychological abuse. Studies have shown a high incidence of child maltreatment in several countries, and child physical abuse (CPA) is the second most prevalent type ${ }^{3-6}$. According to the World Health Organization (WHO), CPA is defined asthe intentional use of force against a child resulting in - or being highly likely to result in - harm to his/her health, survival, development, or dignity ${ }^{5}$.

In 2005, in Brazil, violence against children aged 0 to 9 years, excluding deaths by natural causes, was the first cause of death in this age group in the whole country ${ }^{7}$. According to a survey published in 2017 by the Brazilian Ministry of Health, in 2013 there were 29,784 reports of violence against children aged less than ten years, 50,634 reports against adolescents aged ten to 19 years and approximately $26 \%$ of the reported cases had already suffered some sort of maltreatment in the past ${ }^{8}$. This high incidence makes violencea public health problem, not only in itself, but also for affecting individual and collective health and demanding intersectoral endeavor for its prevention and treatment ${ }^{8,9}$.

Among CPA cases, facial injuries (head and neck), with occasional presence of oral and throat wounds, account $40 \%$ to $75 \%{ }^{10-12}$. This statistic places dental surgeons in a strategic and privileged position for the recognition and reporting of CPA cases.

As dental surgeons are members of the Family Health Strategy (FHS) team, their importance for the initial detection of CPA cases is underscored. The Family Health Strategy is a government policy to the Brazilian primary health care reorganization performed through implementation of family health teams, which are made up of a family physician, nurse, nursing assistant, community health agents and dentists. The FHS seeks to promote quality of life and to step in factors that put population's health at risk. With integral, equitable and continuous attention, the FHS is considered the gateway to the Brazilian health system $^{13}$. Despite being inserted in the
FHS and consequently in a strategic position to identify violence against children, some studies have shown that a significant number of dental surgeons have difficulties and seem to be unable to recognize child physical abuse among their patients ${ }^{14-16}$.

There is a lack of epidemiological data on the recognition and reporting of maltreatment and CPA in Brazil, with no truly representative statistics, as there exists no integrated system for surveillance of these data ${ }^{17}$. Official figures are estimated to hover around $10 \%$ to $30 \%$ of overall cases $^{18}$. These high underreporting rates are observed despite the legal obligation to report substantiated or suspected cases, in compliance with the Statute of Children and Adolescents ${ }^{19}$.

Historically, health professionals have difficulty in recognizing and reporting cases of child physical abuse. Among the main difficulties described in the literature are: lack of previous history of abuse, diagnostic uncertainty, fear of getting involved, lack of knowledge related to child maltreatment and legislation ${ }^{20}$. Another barrier is the secretive behavior underlying the abuse, wich often takes place in children's own homes or in the family environment. ${ }^{1}$

It is the obligation of health professionals, however, to officially report any suspected cases of child abuse. Knowledge about the number of victims, as well as the factors associated with the recognition, reporting, and underreporting of cases plays an important role in the implementation of policies for qualification of professionals, prevention of abuse, and protection of children $^{6,21}$.

Accordingly, the aim of this study was to assess the recognition and reporting of CPA cases by dental surgeons from the FHS teams in Belo Horizonte, Brazil, and to investigate associated factors.

\section{Methods}

This study was approved by the Research Ethics Committees of the Local Department of Health and of Universidade Federal de Minas Gerais. All information provided by the participants was treated as strictly confidential.

This was a cross-sectional study conducted with a representative sample of dental surgeons from the FHS teams in the city of Belo Horizonte, Brazil. According to Brazilian Institute of Geography and Statistics (IBGE) ${ }^{22}$, in 2019, Belo Horizonte, the state capital of Minas Gerais, has 
an estimated population of 2,512,070 inhabitants, being ranked as Brazil's sixth largest city, distributed over a territory of $331,401 \mathrm{~km}^{2}$ and divided into nine administrative regional zones: Barreiro, Mid-South, East, Northeast, Northwest, North, West, Pampulha, and Venda Nova.

The total number of dental surgeons in the FHS teams was obtained from the city Local Department of Health. According to their data, in 2014, Belo Horizonte had 330 (100\%) dental surgeons in the FHS teams distributed among 147 health services centers in the nine regional zones as follow: $53(16.1 \%)$ in Barreiro, 19 $(5.75 \%)$ in Mid-South, $27(8.18 \%)$ in regional East, 44 (13.33\%) in Northeast, $46(13.93 \%)$ in Northwest, 44 (13.33\%) in North, 33 (10.0\%) in West, 16 (4.84\%) in Pampulha and 48 (14.54\%) in Venda Nova. The data were collected from August 2014 to September 2015.

Sample size was estimated on a proportion for finite populations usingthe EpiInfo program, version 3.5.2. For the sample calculation, the $56 \%$ prevalence of "recognition of CPA" was estimated in a previous pilot study ${ }^{23}$. A 95\% confidence interval and a sampling error no greater than 5\% were adopted. The minimum sample eventually comprised 177 dentists, representing 53,6\% of the total $(n=330)$ in Belo Horizonte and this number was used to achieve the proportionality of the minimum sample size. The final study sample consisted of 181 professionals.

A simple random draw performed by Microsoft Excel, version 2013, was used for sample selection. This selection obeyed the proportionality of dentists distributed in each of the nine regional zones and all 147 health centers were considered, thus guaranteeing random selection and the representativeness. After selection in each regional zone, the final sample consisted of: 35 (19.3\%) professionals in regional Barreiro, $9(5 \%)$ in MidSouth, $15(8.3 \%)$ in regional East, $29(16 \%)$ in Northeast, 24 (13.3\%) in Northwest, 17 (9.4\%) in North, 18 (9.9\%) in West, 8 (4.4\%) in Pampulha and $26(14.4 \%)$ in Venda Nova. Dentists with a workload of 40 weekly hours and members of FHS teams were included in the study.

The data were collected using a substitution model and, therefore, those dentists on a leave of absence, those who were relocated, or those who were no longer working in the public health sector, or also those who refused to participate in the study were replaced by other dentists, selected randomly, in order to maintain the minimum sample size and the representativeness of the study. Every time a new draw was made, a new schedule with the list of dentists who were working at health centers was requested from the Local Department of Health so as to keep the list of dentists up-to-date. Therefore, there were no inclusions in the sample to correct for distortions.

The data were collected through a self-administered questionnaire developed by the University of London ${ }^{24,25}$, which was cross-culturally adapted to and validated for use in Brazille,26. The questionnaire was devised with the purpose of assessing the frequency of recognition andreportingof CPA by primary heathcare workers as well as any factors associated with its outcomes.

The questionnaire was comprised of three parts, totaling 19 questions. The first part contained personal questions about sex, age, employment as municipal worker, graduate degrees, among others. The second part contained questions about professional experience in the recognition and reporting of CPA cases. The third part contained questions about the major motivating factors and the major hindrances associated with the recognition and reporting of CPA.

Initially, for data collection, primary healthcare managers and administrators were contacted in each regional unit. Managers of the health centers were asked to put the objectives and details of the present study on the agenda for the weekly meetings. At these meetings, a researcher randomly selected the dentists and the managers were asked to forward the questionnaires to the selected dentists. The questionnaire and two copies of the informed consent form were handed over in a brown envelop containing the addressee's name. A sticker was also supplied so that the dentist could seal the envelope and hand it back to the manager, thereby preserving the confidentiality of the data and reducing the possibility of biases. The envelopes were collected by the researchers on a date that had been set with the health center managers.

Approximately $50 \%$ of the questionnaires were answered. To complete the others $50 \%$ of the sample, a new random draw was performed and the questionnaires were delivered to the selected dental surgeons. A new meeting was arranged for handing these questionnaires. To reduce sample losses, three researchers personally sought those professionals who were reluctant in participating in the study. Later on, the remainder of the questionnaires was directly applied by the researcher sat the health centers, in order to make up nearly $25 \%$ of the sample.

The statistical analyses were performed in the Statistical Package for Social Sciences (SPSS), 
version 20.0 for Windows. The outcome variables were "recognition of CPA cases" and "reporting of CPA cases", and both categorical and nominal variables were dichotomized into yes/no.

The independent variables "age", "duration of employment", "duration of employment as municipal worker", and "duration of employment at the health center" were recategorized by taking into account the terciles and then turned into nominal variables. Those variables rated on a scale from 0 to 10 , "ability to diagnose CPA cases" and "willingness to engage in the detection of CPA cases", were transformed, by using the terciles as cut off points, into nominal variables, classified as "low", "moderate", and "high". The independent variable "know what protection service the report should be presented to" was categorized into "does not know or did not answer", "Child Protective Services or National Information System for Notifiable Diseases (SINAN)", and "other agencies". The variable "graduate degree" was categorized into "did not take a graduate degree", "no major in childcare", and "major in childcare".

Statistical analys is included univariate and multiple analyses through Poisson regression. The univariate Poisson regression $(P=0.05)$ was performed for both "recognition of CPA cases" and "reporting of CPA cases" outcomes. Some variables with significance $\leq 25 \%$ for the univariate analysis, non-collinear variables, and variables considered to be important for the model's fit were included in the multiple analysis. The multiple Poisson regression analysis was performed only for "recognition of CPA cases" because of the very small number of reports, which did not allow for the analysis of this outcome.

\section{Results}

A total of 181 dental surgeons - 50 men (27.6\%) and 131 women $(72.4 \%)$ - from FHS teams participated in the study. The mean age was $45( \pm$ SD $11,6)$ years, the mean professional experience was $22( \pm$ SD 11,2$)$ years, and the duration of employment was $8( \pm$ SD 7,2$)$ years in the FHS team at the same unit.

Of the 181 participants, 73 (40.3\%) had already recognized some instance of CPA during their professional career, whereas $11(6.1 \%)$ reported it to the authorities. This reveals $84.9 \%$ non-reporting behavior rate.

Table 1 shows the distribution of the sample regarding "recognition of CPA cases" by means of descriptive variables as well as the results for univariate Poisson regression analysis. The independent variables "duration of employment as municipal worker" $(P=0.038)$ and "employment at the unit" $(P=0.024)$ were associated with the recognition of CPA cases. Dental surgeons with 6 to 19 years' experience as a municipal worker presented 1.88 times [PR $=1.88$ (95\%CI: 1.033.44)] more probability to recognize cases of CPA than the ones with less than six years of experience. In addition, dental surgeons with four to ten years working at the same unit presented 1.64 times [PR $=1.64$ (95\%CI: 1.06-2.52)] more probability to recognize CPA when compared to the ones with less than four years.

Table 2 displays the multiple Poisson regression analysis results for "recognition of CPA cases". The independent variable "duration of employment as municipal worker" was positively associated with the recognition of CPA cases, revealing that dental surgeons with 6 to 19 years' experience presented 2.38 times $[\mathrm{PR}=2.38$ (95\%CI: $1.29-4.41)]$ more probability to recognize cases of CPA than the ones with less than six years of experience.

Table 3 displays the distribution of the sample regarding "reporting of CPA cases" by means of descriptive variables as well as the results for univariate Poisson regression analysis. Note that having a graduate degree with a major in childcare $(P=0.038)$ was positively associated with the reporting of CPA cases. Dental surgeons who completed a graduate program with a major in childcare presented 4.05 times [PR $=4.50$ (95\%CI: 1.08-18.68)] more probability to report a CPA case than the ones without a complete graduate degree.

\section{Discussion}

This research was conducted to assess the recognition and reporting of CPA cases by dental surgeons from the FHS team and to investigate associated factors. The results revealed that even though dental surgeons said they managed to recognize CPA cases among their patients, few reported such cases. Long-term professionals working in the municipality were associated with a larger number of recognition of CPA and professionals who had a graduate degree with major in child care were associated with a larger number of reports.

Of the interviewed dental surgeons, more than a half said they had never suspected of CPA 
Table 1. Distribution of the sample based on the frequency of CPA recognition and independent variables, and univariate Poisson regression analysis for "recognition of CPA cases”, Belo Horizonte, Minas Gerais, Brazil, 2015.

\begin{tabular}{|c|c|c|c|c|c|}
\hline \multirow[b]{2}{*}{ Independent variables } & \multirow[b]{2}{*}{$\begin{array}{l}\text { Frequency } \\
\quad \mathbf{n}(\%)\end{array}$} & \multicolumn{2}{|c|}{ Recognition of $\mathrm{CPA}^{\star \star}$ cases } & \multirow[b]{2}{*}{$\begin{array}{l}\text { Recognized CPA }{ }^{\star *} \\
\text { Crude PR 95\% CI* }\end{array}$} & \multirow[b]{2}{*}{$\begin{array}{c}\text { P- } \\
\text { value }\end{array}$} \\
\hline & & $\begin{array}{c}\text { No } \\
\mathbf{n}(\%)\end{array}$ & $\begin{array}{l}\text { Yes } \\
\text { n (\%) }\end{array}$ & & \\
\hline \multicolumn{6}{|l|}{ Sex } \\
\hline Male & $50(27.6)$ & $28(56.0)$ & $22(44.0)$ & $1.13(0.77-1.65)$ & 0.527 \\
\hline Female & $131(72.4)$ & $80(61.1)$ & $51(38.9)$ & 1 & \\
\hline \multicolumn{6}{|l|}{ Age } \\
\hline 24 to 39 years & $58(32.8)$ & $40(69.0)$ & $18(31.0)$ & 1 & \\
\hline 40 to 52 years & $60(33.9)$ & $33(55.0)$ & $27(45.0)$ & $1.45(0.90-2.33)$ & 0.125 \\
\hline 53 to 68 years & $59(33.3)$ & $33(55.9)$ & $26(44.1)$ & $1.42(0.87-2.29)$ & 0.152 \\
\hline \multicolumn{6}{|l|}{ Duration of employment } \\
\hline 1 to 13 years & $60(34.1)$ & $41(68.3)$ & $19(31.7)$ & 1 & \\
\hline 14 to 28 years & $63(35.8)$ & $36(57.1)$ & $27(42.9)$ & $1.35(0.84-2.16)$ & 0.205 \\
\hline 29 to 42 years & $53(30.1)$ & $28(52.8)$ & $25(47.2)$ & $1.49(0.93-2.37)$ & 0.095 \\
\hline \multicolumn{6}{|l|}{ Employment as municipal worker } \\
\hline 1 to 5 years & $48(36.1)$ & $36(75.0)$ & $12(25.0)$ & 1 & \\
\hline 6 to 19 years & $36(27.1)$ & $19(52.8)$ & $17(47.2)$ & $1.88(1.03-3.44)$ & 0.038 \\
\hline 20 to 42 years & $49(36.8)$ & $30(61.2)$ & $19(38.8)$ & $1.55(0.84-2.83)$ & 0.154 \\
\hline \multicolumn{6}{|l|}{ Employment at the unit } \\
\hline 0 to 3 years & $71(39.9)$ & $48(67.6)$ & $23(32.4)$ & 1 & \\
\hline 4 to 10 years & $47(26.4)$ & $22(46.8)$ & $25(53.2)$ & $1.64(1.06-2.52)$ & 0.024 \\
\hline 11 to 30 years & $60(33.7)$ & $35(58.3)$ & $25(41.7)$ & $1.28(0.82-2.01)$ & 0.273 \\
\hline \multicolumn{6}{|l|}{ Ability to diagnose CPA } \\
\hline Low & $49(27.2)$ & $30(61.2)$ & $19(38.8)$ & $1.08(0.67-1.74)$ & 0.733 \\
\hline Moderate & $61(33.9)$ & $32(52.5)$ & $29(47.5)$ & $1.33(0.88-2.00)$ & 0.172 \\
\hline High & $70(38.9)$ & $45(64.3)$ & $25(35.7)$ & 1 & \\
\hline \multicolumn{6}{|l|}{$\begin{array}{l}\text { Willingness to engage in the } \\
\text { detection of CPA }\end{array}$} \\
\hline Low & $61(33.7)$ & $40(65.6)$ & $21(34.4)$ & $0.72(0.47-1.11)$ & 0.140 \\
\hline Moderate & $46(25.4)$ & $29(63.0)$ & $17(37.0)$ & $0.78(0.49-1.22)$ & 0.280 \\
\hline High & $74(40.9)$ & $39(52.7)$ & $35(47.3)$ & 1 & \\
\hline \multicolumn{6}{|l|}{ Graduate degree } \\
\hline Did not take a graduate degree & $45(25.1)$ & $26(57.8)$ & $19(42.2)$ & 1 & \\
\hline Without a major in childcare & $129(72.1)$ & $77(59.7)$ & $52(40.3)$ & $0.95(0.63-1.42)$ & 0.821 \\
\hline With a major in childcare & $05(2.8)$ & $03(60.0)$ & $02(40.0)$ & $0.94(0.30-2.92)$ & 0.925 \\
\hline \multicolumn{6}{|l|}{ Completed a graduate program } \\
\hline No & $33(19.2)$ & $19(57.6)$ & $14(42.4)$ & $1.01(0.65-1.58)$ & 0.942 \\
\hline Yes & $139(80.8)$ & $81(58.3)$ & $58(41.7)$ & 1 & \\
\hline
\end{tabular}

${ }^{\star} \mathrm{CI}$ : confidence interval; ${ }^{* *} \mathrm{CPA}$ : child physical abuse.

Source: Authors' elaboration.

in their routine practice. Among the professionals who said they had already suspected of CPA among their patients, $84.9 \%$ (62) did not report it to the authorities. These data indicates a very high rate of non-reporting behavior. A similar result was found in a study involving 212 primary healthcare dentists in the state of Ceará, Brazil. Among the professionals who had already identified any case of child maltreatment, only $16.9 \%$ reported to the authorities, representing an underreporting rate of $83.1 \%{ }^{14}$. It is clear in the literature that the difficulties in identifying cases of child maltreatment and CPA, as well as the high rates of underreporting by dental surgeons, are not a Brazilian exclusivity. A survey conducted in Northern Ireland with primary heathcare workers showed that dentists were the professionals with the highest underreporting rates ${ }^{24}$. These findings are in line with some studies that found a low number of cases of child abuse reported by dentists $^{2,25,16,27}$.

In Brazil, evidence indicates that primary healthcare workers are key to the recognition and reporting of CPA cases ${ }^{7,28,29}$. FHS teams are com- 
Table 2. Multiple Poisson regression analysis for "recognition of CPA case" and associated factors among dentists from the FHS team $(n=181)$, Belo Horizonte, Minas Gerais, Brazil, 2015.

\begin{tabular}{|c|c|c|c|c|}
\hline Independent variables & $\begin{array}{l}\text { Recognized CPA**} \\
\text { Crude PR 95\% CI* }\end{array}$ & $\begin{array}{c}\text { P- } \\
\text { value }\end{array}$ & $\begin{array}{c}\text { Recognized CPA }{ }^{\star *} \\
\text { adjusted PR 95\% } \mathrm{CI}^{\star}\end{array}$ & $\begin{array}{c}\mathrm{P}- \\
\text { value }\end{array}$ \\
\hline \multicolumn{5}{|c|}{ r } \\
\hline Female & 1 & & 1 & \\
\hline Male & $1.13(0.77-1.65)$ & 0.527 & $1.20(0.74-1.95)$ & 0.449 \\
\hline \multicolumn{5}{|l|}{ Employment as municipal worker } \\
\hline 1 to 5 years & 1 & & 1 & \\
\hline 6 to 19 years & $1.88(1.03-3.44)$ & 0.038 & $2.38(1.29-4.41)$ & 0.005 \\
\hline 20 to 42 years & $1.55(0.84-2.83)$ & 0.154 & $1.87(1.00-3.52)$ & 0.050 \\
\hline \multicolumn{5}{|c|}{ Willingness to engage in the detection of $\mathrm{CPA}^{* *}$} \\
\hline Low & $0.72(0.47-1.11)$ & 0.140 & $0.77(0.45-1.31)$ & 0.340 \\
\hline Moderate & $0.78(0.49-1.22)$ & 0.280 & $0.92(0.53-1.59)$ & 0.765 \\
\hline High & 1 & & 1 & \\
\hline \multicolumn{5}{|l|}{ Completed a graduate program } \\
\hline No & $1.01(0.65-1.58)$ & 0.942 & $1.51(0.84-2.68)$ & 0.160 \\
\hline Yes & 1 & & 1 & \\
\hline
\end{tabular}

Source: Authors' elaboration.

Table 3. Distribution of the sample based on the frequency of CPA reporting and independent variables, and univariate Poisson regression analysis for reporting of CPA cases, Belo Horizonte, Minas Gerais, Brazil, 2015.

\begin{tabular}{|c|c|c|c|c|c|}
\hline \multirow[b]{2}{*}{ Independent variables } & \multirow[b]{2}{*}{$\begin{array}{c}\text { Frequency } \\
\text { n (\%) }\end{array}$} & \multicolumn{2}{|c|}{ Reporting of $\mathrm{CPA}^{\star *}$ cases } & \multirow{2}{*}{$\begin{array}{c}\text { Reported CPA }{ }^{\star *} \\
\text { Crude PR 95\% } \\
\text { CI }^{\star}\end{array}$} & \multirow[b]{2}{*}{$\begin{array}{c}\text { P- } \\
\text { value }\end{array}$} \\
\hline & & $\begin{array}{c}\text { No } \\
\text { n }(\%) \\
\end{array}$ & $\begin{array}{c}\text { Yes } \\
\text { n (\%) }\end{array}$ & & \\
\hline \multicolumn{6}{|l|}{ Sex } \\
\hline Male & $50(27.6)$ & $47(94.0)$ & $03(6.0)$ & $0.98(0.27-3.55)$ & 0.979 \\
\hline Female & $131(72.4)$ & $123(93.9)$ & $08(6.1)$ & 1 & \\
\hline \multicolumn{6}{|l|}{ Age } \\
\hline 24 to 39 years & $58(32.8)$ & $56(96.6)$ & $02(3.4)$ & 1 & \\
\hline 40 to 52 years & $60(33.9)$ & $59(98.3)$ & $01(1.7)$ & $0.48(0.04-5.18)$ & 0.548 \\
\hline 53 to 68 years & $59(33.3)$ & $52(88.1)$ & $07(11.9)$ & $3.44(0.74-15.87)$ & 0.113 \\
\hline \multicolumn{6}{|l|}{ Employment as municipal worker } \\
\hline 1 to 5 years & $48(36.1)$ & 47 (97.9) & $01(2.1)$ & 1 & \\
\hline 6 to 19 years & $36(27.1)$ & $33(91.7)$ & $03(8.3)$ & $4.00(0.43-36.88)$ & 0.221 \\
\hline 20 to 42 years & $49(36.8)$ & $45(91.8)$ & $04(8.2)$ & $3.91(0.45-33.80)$ & 0.214 \\
\hline \multicolumn{6}{|l|}{ Employment at the unit } \\
\hline 0 to 3 years & $71(39.9)$ & $69(97.2)$ & $02(2.8)$ & 1 & \\
\hline 4 to 10 years & $47(26.4)$ & $44(93.6)$ & $03(6.4)$ & $2.26(0.39-13.05)$ & 0.360 \\
\hline 11 to 30 years & $60(33.7)$ & $54(90.0)$ & $06(10.0)$ & $3.55(0.74-16.94)$ & 0.112 \\
\hline \multicolumn{6}{|l|}{ Willingness to engage in the detection } \\
\hline of CPA & & & & & 0.126 \\
\hline Low & $61(33.7)$ & $59(96.7)$ & $02(3.3)$ & 1 & \\
\hline Moderate & $46(25.4)$ & $45(97.8)$ & $01(2.2)$ & $0.66(0.06-7.09)$ & 0.734 \\
\hline High & $74(40.9)$ & $66(89.2)$ & $08(10.8)$ & $3.29(0.72-14.95)$ & 0.122 \\
\hline \multicolumn{6}{|l|}{ Completed a graduate program } \\
\hline No & $45(25.1)$ & $41(91.1)$ & $04(8.9)$ & 1 & \\
\hline Without a major in childcare & $129(72.1)$ & $124(96.1)$ & $05(3.9)$ & $0.43(0.12-1.55)$ & 0.200 \\
\hline With a major in childcare & $05(2.8)$ & $03(60.0)$ & $02(40.0)$ & $4.50(1.08-18.68)$ & 0.038 \\
\hline $\begin{array}{l}\text { Knows to which agency the report } \\
\text { should be presented }\end{array}$ & & & & & 0.360 \\
\hline Does not know or did not answer & $70(38.7)$ & $67(95.7)$ & $03(4.3)$ & 1 & \\
\hline Child protection service or SINAN & $59(32.6)$ & $53(89.8)$ & $06(10.2)$ & $0.89(0.15-5.17)$ & 0.904 \\
\hline Other agencies & $52(28.7)$ & $50(96.2)$ & $02(3.8)$ & $2.37(0.62-9.08)$ & 0.207 \\
\hline
\end{tabular}

${ }^{\star} \mathrm{CI}$ : confidence interval; ${ }^{* \star} \mathrm{CPA}$ : child physical abuse.

Source: Authors' elaboration. 
prised of at least one nurse and one family doctor, and a dental surgeon is added to oral health teams. The FHS is the gateway to public health services in Brazil, bringing health professionals closer to the communities, allowing them to adjust the services to suit specific needs of the patients ${ }^{30}$. Dentists, as health professionals, should be watchful so that they can recognize and report any suspect abuse; otherwise, they can be held legally responsible for failing to comply with the regulations set forth by the Statute of Children and Adolescents ${ }^{19}$.

Few studies have investigated and assessed the activity of health professionals, who can play a pivotal role in the reporting of CPA cases. Dental surgeons are among the main professional categories capable of recognizing and reporting CPA cases since the head, face, and neck regions are often affected. It should be highlighted that head and neck injuries are the most severe outcomes of physical violence against children and adolescents $\mathrm{s}^{10}$. Thus, the importance of dental surgeons in the recognition of abuse should not be overlooked.

By looking at the high rate of non-reporting behavior observed in the present study and in similar studies carried out with health professionals ${ }^{14,16,25,31}$, one perceives the need of further investigation into the factors related to these low reporting rates that could provide clearer evidence and contribute to the debate on this topic, allowing for new measures and public policies for the prevention of child abuse and for the health support of children and adolescents.

The inability of professionals to recognize child maltreatment may be attributed to factors such aslack of training in and reading about $\mathrm{CPA}$, failure to incorporate this subject into the curriculum of undergraduate programs, and limitations of the working process model for primary healthcare. Carvalho et al. ${ }^{27}$ conducted a study in the city of São Paulo with 80 dental surgeons from the public and private health sector, and most of them said they had not studied this problem in college. Therefore, health professionals feel insecure and unprepared to recognize and report such events. The importance of addressing this topic in undergraduate and graduate programs was observed in the present study, as having a graduate degree with a major in childcare was positively associated $(P=0.038)$ withthe reporting of CPA cases.

Being unfamiliar with or lacking knowledge about the reporting record, not having confidence in child and adolescent protection services, not knowing to which protection service the report must be presented, and showing fear of litigation are some of the hindrances to reporting described by health professionals ${ }^{18,20}$. Andrade-Lima et al..$^{32}$, in a study conducted with pediatric dentists demonstrated that diagnostic uncertainty, i.e., not knowing whether violence had actually occurred, was the major reason for not reporting suspect cases of violence to the authorities. This also shows lack of information about the legal obligation to report these cases, as established by a Brazilian federal law ${ }^{19}$.

Recognizing CPA is not an easy task and requires a multidisciplinary approach on the part of health professionals. In order to recognize a case of CPA, the dentist has to be alert and have a holistic view of the patient and of his/ her health. More often than not, it is necessary to assess physical signs and symptoms and behavorial and psychological signs to substantiate a CPA $\operatorname{case}^{33-35}$.The FHS team encompasses different health areas and specialties. Consequently, interdisciplinary or multidisciplinary work is possible, being an integral part of the working process model in primary healthcare. However, studies have shown that dentists do not establish a professional link with the other professionals in FHS teams. Moreover, they use quite technical and curative practices, focused exclusively on the oral health, thereby failing to achieve an integration of health services. This may explain, to some extent, the low rates of recognition and reporting of child maltreatment in the present study and also in line with other studies ${ }^{30,36,37}$.

Professional experience and closer contact with a larger number of CPA cases, in addition to clinical experience could make the difference when recognizing and reporting such events, as corroborated in the present study and similar investigations. In a study undertaken in Pelotas, southern Brazil, Azevedo et al. ${ }^{38}$ observed that dentists with 21 to 30 years' experience suspected of child maltreatment more frequently. Kaur et al. ${ }^{39}$ demonstrated that having more years of experience was associated with greater ability to distinguish between accidental injuries and those caused by CPA. The present study revealed that the professionals with 6 to 19 years of duration as a municipal worker were associated with a greater number of recognitions of CPA $(P=0.005)$ when compared to professionals with a lower duration. However, when durations of municipal work higher than 19 years were observed there was no significant association. One hypothesis to be considered is that the thorough investigation 
that leads to the recognition of CPA is in opposition to the older academic formation of these professionals with the longest working time. A training with curativist focus that did not contemplate the thought of health in an integral and extended way, reflecting in the lack of preparation for the interdisciplinar $\operatorname{look}^{30}$. Another issue to be considered to justify this finding is the fact that the professionals with 6 to 19 years of duration as municipal workers were, probably, at the peak of their careers and therefore more motivated to be involved in the recognition of maltreatment when compared to professionals with longer duration as municipal worker as they are already approaching the end of their professional career.

There were some limitations in the present study. Given its cross-sectional design, the study could only make associations between factors and outcomes, and no causal inference could be established. As this is a retrospective data collection performed through self-administered questionnaires, we need to consider the possibility of introducing memory bias in our study. In addition, we have not reached the minimum number of dentists expected in Mid-Southand Pampulha regions but the minimun number of the total sample has been reached. While this study found some reports of CPA, their number was too low. With only 11 reports among 73 suspect cases, it was not possible to use the multiple analysis for the reporting outcome. Nonetheless the study is of relevance because the topic has been poorly explored in the literature on the frequency of recognition and reporting of CPA cases by dental surgeons.

A high rate of non-reporting behavior was observed in this study despite the fact that the interviewers demonstrated willingness to recognize CPA cases. This shows that, in addition to their willingness, it is necessary that dental surgeons from the FHS teams to be properly prepared to recognize these problems and fulfill their duties as health professionals by reporting these cases to the appropriate authorities. Dental surgeons are crucial for the protection of children and adolescents, as long as they are sufficiently skilled for that. It is paramount that these professionals be confident, motivated, and encouraged to report CPA cases. After all, they are among the professionals with greater chances to recognize physical violence against children, not only because the face is the part of the body with the highest prevalence of injuries, but also because they have the opportunity to observe the behavior and relationship between the child and his/her legal guardians during several visits for a long time period.

It has become evident that further qualitatives investigations are needed to elucidate the factors associated with child maltreatment and CPA cases, recognized and reported by health professionals in the Brazilian public health sector. Studies contribute to the understanding of the current situation and of the reporting patterns adopted in Brazil, as well as of the factors associated with it, and also contribute to future reflection, discussions, and measures targeted at the FHS andat undergraduate and graduate curriculumof dental schoolsas far as CPA is concerned.

\section{Conclusions}

Despite the considerable prevalence of CPA recognition found in this study, the prevalence of CPA reporting was low. The duration of employment as municipal worker was positively associated with the regognition of CPA cases and having a graduate degree with a major in childcare was associated with a larger number of reports. 


\section{Collaborations}

LS Nunes: responsible for data analysis and conception of the article. F Silva-Oliveira: responsible for the conception of the study, data collection, data analysis and revision of the manuscript. FF Mattos: responsible for the conception and revision of the manuscript. FB Freire-Maia: responsible for revision of the manuscript. EF Ferreira: responsible for the conception and revision of the manuscript. PMPA Zarzar: responsible for the conception of the study, data analysis and revision of the manuscript.

\section{Acknowledgments}

This study was financed in part by the Coordenação de Aperfeiçoamento de Pessoal de Nível Superior - Brasil (CAPES) and by Fundação de Amparo à Pesquisa do Estado de Minas Gerais (FAPEMIG).

\section{References}

1. Costa MCO, Carvalho RC, Bárbara JRFS, Santos CAST, Gomes WDA, Sousa HL. The profile of violence against children and adolescents according to Child Protection Council records: victims, aggressors and patterns of violence. Cien Saude Colet 2007; 12(5):1129-1141.

2. Fracon ET, Silva RHA, Bregagnolo JC. Evaluation of dentist's behavior regarding domestic violence against children and adolescents in the city of Cravinhos (São Paulo - Brazil). RSBO 2011; 8(2):153-159.

3. Malta DC, Bernal RTI, Teixeira BSM, Silva MMAD, Freitas MIF. Factors associated with violence against children in sentinel urgent and emergency care centers in Brazilian capitals. Cien Saude Colet 2017; 22(9):2889-98

4. U.S. Department of Health \& Human Services, Administration for Children and Families, Administration on Children, Youth and Families. Child maltreatment 2017. Washington, DC: Children's Bureau; 2019. [cited 2020 Jan 8]. Available from: https://www.acf.hhs. gov/cb/resource/child-maltreatment-2017

5. World Health Organization, International Society for Prevention of Child Abuse and Neglect. Preventing child maltreatment: a guide to taking action and generating evidence. Geneva: World Health Organization; 2006.

6. Gilbert R, Widom CS, Browne K, Fergusson D, Webb E, Janson S. Burden and consequences of child maltreatment in high-income countries. Lancet 2009; 373(9657):68-81.

7. Martins CBG, Jorge MHPM. Violence against children and adolescents: epidemiological information based on cases reported to Juvenile Courts and Child Protective Services in a municipality in the South of Brazil, 2002 and 2006. Epidemiol Serv Saude 2009; 18(4):315-334.

8. Brasil. Ministério da Saúde (MS), Secretaria de Vigilância em Saúde, Departamento de Vigilância de Doenças e Agravos não Transmissíveis e Promoção de Saúde. Sistema de vigilância de violências e acidentes (Viva): 2013 e 2014 [Internet]. Brasília: MS; 2017. [cited 2020 Jan 08]. Available from: http://bvsms. saude.gov.br/bvs/publicacoes/viva_vigilancia_violencia_acidentes_2013_2014.pdf

9. Brasil. Ministério da Saúde (MS), Secretaria de Vigilância em Saúde. Impacto da violência na saúde dos brasileiros [Internet]. Brasília: MSe; 2005. [cited 2019 Oct 1]. Available from: http://bvsms.saude.gov.br/ bvs/publicacoes/impacto_violencia.pdf

10. Cavalcanti AL. Prevalence and characteristics of injuries to the head and orofacial region in physically abused children and adolescents - a retrospective study in a city of the Northeast of Brazil. Dent Traumatol 2010; 26(2):149-153

11. Fonseca MA, Feigal RJ, ten Bensel RW. Dental aspects of 1,248 cases of child maltreatment on file at a major county hospital. Pediatr Dent 1992; 14(3):152-157.

12. Vidal HG, Caldas IM, Coelho Júnior LGTM, Souza EHA, Carvalho MVD, Soriano EP, Pereira ML, Caldas Jr AF. Orofacial injuries in child and adolescents (2009-2013): a 5-year study in Porto, Portugal. Braz Dent J 2018; 29(3):316-320. 
13. Paim J, Travassos C, Almeida C, Bahia L, Macinko J. O sistema de saúde brasileiro: história, avanços e desafios [Internet]. Lancet 2017. [cited 2019 Oct 1]. Available from: http://www.scielo.br/scielo.php?script=sci_nlinks\&pxml:id=S1519 382920150001000 3300022\&lng=en

14. Moreira GAR, Rolim ACA, Saintrain MVL, Vieira LJES. Dental surgeons' work in the identification of child and adolescent abuse in primary healthcare. Saude Debate 2015; 39(special):257-267.

15. Martins-Júnior PA, Ribeiro CD, Peruch GSO, Paiva SM, Marques LS, Ramos-Jorge ML. Physical abuse of children and adolescents: do health professionals perceive and denounce? Cien Saude Colet 2019; 24(7):2609-2616

16. Silva Oliveira F, Andrade CI, Guimarães MO, Ferreira RC, Ferreira EF, Zarzar PM. Recognition of child physical abuse by a group of Brazilian primary care health professionals. Int J PaediatrDent 2019; 29:624-634.

17. Silva Franzin LC, Olandovski M, Vettorazzi ML, Werneck RI, Moysés SJ, Kusma SZ, Moysés ST. Child and adolescent abuse and neglect in the city of Curitiba, Brazil. Child Abuse Negl 2014; 38(10):1706-1714.

18. Bazon MR. Violence against children and adolescents: ananalysis of four years of complaints filed at the Child Protection Agency in Ribeirão Preto, São Paulo State, Brazil. Cad Saude Publica 2008; 24(2):323-332.

19. Brasil. Lei $n^{\circ} 8.069$, de 13 de julho de 1990. Dispõe sobre o Estatuto da Criança e do Adolescente e dá outras providências. [cited 2019 Oct 1]. Available from: http://www.planalto.gov.br/ccivil_03/leis/18069.htm

20. Borimnejad L, Fomani FK. Child abuse reporting barriers: Iranian nurses' experiences. Iran Red Crescent Med J 2015; 17(8):e22296.

21. Gilbert R, Kemp A, Thoburn J, Sidebotham P, Radford L, Glaser D, Macmillan HL. Recognising and responding to child maltreatment. Lancet 2009; 373(9658):167-1680.

22. Instituto Brasileiro de Geografia e Estatística (IBGE). [internet]. [cited 2019 Oct 1]. Available from: https:// cidades.ibge.gov.br/brasil/mg/belo-horizonte/panorama

23. Silva-Oliveira F, Ferreira EF, Mattos FF, Ribeiro MTF, Cota LOM, Vale MP, Zarzar PM. Cross-cultural adaptation and reproducibility of a questionnaire to assess the knowledge and attitude of health professionals in cases of child physical abuse. Cien Saude Colet 2014; 19(3):917-929.

24. Lazenbatt A, Freeman R. Recognizing and reporting child physical abuse: A survey of primary healthcare professionals. J Adv Nurs 2006; 56(3):227-236.

25. Russell M, Lazenbatt A, Freeman R, Marcenes W. Child physical abuse: health professionals' perceptions, diagnosis and responses. Br J Community Nurs 2004; 9(8):332-338.

26. Marengo G, Paola AP, Ferreira FM, Pizzatto E, Correr GM, Losso EM. Child abuse: validation of a questionnaire translated into Brazilian Portuguese. Bras Oral Res 2013; 27(2):163-168.

27. Carvalho LMF, Galo R, Silva RHA. O cirurgião-dentista frente à violência doméstica: conhecimento dos profissionais em âmbito público e privado. Medicina (Ribeirão Preto) 2013; 46(3):297-304.
28. Luna GL, Ferreira RC, Vieira LJ. Mandatory reporting of child abuse by professionals of Family Health Teams. Cien Saude Colet 2010; 15(2):481-491.

29. Moreira GA, Vieira LJ, Deslandes SF, Pordeus MA, Gama Ida S, Brilhante AV. Factors associated with the report and adolescent abuse in primary healthcare. Cien Saude Colet 2014; 19(10):4267-4276.

30. Mattos GC, Ferreira EF, Leite IC, Greco RM. The inclusion of the oral health team in the Brazilian Family Health Strategy: barriers, advances and challenges. Cien Saude Colet 2014; 19(2):373-382.

31. Sonbol HN, Abu-Ghazaleh S, Rajab LD, Baqain ZH, Saman R, Al-Bitar ZB. Knowledge, educational experiences and attitudes towards child abuse amongst Jordanian dentists. Eur J Dent Educ 2012; 16(1):e15865.

32. Lima KA, Colares V, Cabral HM. Evaluation of pediatric dentist's attitudes towards the child abuse in Recife. Rev Odontocienc 2005; 20(49):231-236.

33. Duda JG, Biss SP, Bertoli FMP, Bruzamolin CD, Pizzatto E, Souza JF, Losso EM. Oral health status in victims of child abuse: a case-control study. Int J Paediatr Dent 2017; 27(3):210-216.

34. Massoni AC, Ferreira AM, Aragão AK, Menezes VA, Colares V. Orofacial aspects of childhood abuse and dental negligence. Cien Saude Colet 2010; 15(2):403410.

35. Costacurta M, Benavoli D, Arcudi G, Docimo R. Oral and dental signs of child abuse and neglect. Oral Implantol (Rome) 2016; 8(2-3):68-73.

36. Cericato GO, Garbin D, Fernandes APS. Surgeondentist insertion in the Family Health Program: a critical revision on the actions and evaluation methods of the Oral Health Team. RFO UPF 2007; 12(3):18-23.

37. Moretti AC, Teixeira FF, Suss FM, Lawder JA, Lima LS, Bueno RE, Moysés SJ, Moysés ST. Intersectoriality in health promotion actions carried out by the oral health team of Curitiba, Paraná State. Cien Saude Colet 2010; 15(suppl. 1):1827-1834.

38. Azevedo MS, Goettems ML, Brito A, Possebon AP, Domingues J, Demarco FF, Torriani DD. Child maltreatment: a survey of dentists in southern Brazil. Braz Oral Res 2012; 26(1):5-11.

39. Kaur H, Vinod KS, Singh H, Arya L, Verma P, Singh B. Child maltreatment: cross-sectional survey of general dentists. J Forensic Dent Sci 2017; 9(1):24-30.

Article submitted 11/03/2019

Approved 24/02/2020

Final version submitted 26/02/2020

Chief editors: Romeu Gomes, Antônio Augusto Moura da Silva 